\title{
Domestic Terrorism in the Islamic Legal Tradition ${ }^{1}$
}

\author{
Sherman A. Jackson \\ University of Michigan \\ Ann Arbor, Michigan
}

7 errorism as a legal category in American law is quite recent in origin. The term itself did not come into popular usage until the $1960 \mathrm{~s}^{2}$ In

1 the 1970s, FBI Director William Webster changed the designation covering investigations into certain crimes from "domestic security" to "terrorism." ${ }^{\text {3 }}$ Still, according to B.L. Smith, as late as 1994, no federal crime called terrorism as such existed. ${ }^{4}$ It would not be until April of 1996 that the Clinton administration would pass the now much-talked about Anti-Terrorism and Effective Death Penalty Act (Pub. Law 104-132). One of the more abstruse side effects of terrorism's late and uneasy induction into the American legal lexicon has been that Western scholars (Muslim and non-Muslim alike) have devoted scant attention to the Islamic legal definition of terrorism. Experts on Islam and the Middle East routinely speak about terrorism in political, moral, religious or even clash-of-civilization terms. Analogous Islamic legalcategories, meanwhile, remain buried beneath an array of archaic and misleading designations such as "brigandage," "banditry" or "highway robbery." These were the terms in use at the time the study of Islamic law was first taken up in the West, and under the weight of scholarly tradition, they have maintained their hegemony as translations for the Islamic legal category of biräbab or qat 'al-tariq, despite the obvious parallels between the latter and terrorism. As a result of this obfuscation, there has yet to appear a solid Islamic legal treatment of terrorism. ${ }^{5}$

Close examination of the classical Islamic law of birabah, however, reveals that this law corresponds in its most salient features to domestic terrorism in the American legal system. This holds despite a number of important differences between birabab and domestic terrorism. First, the importance of the political motivations of would-be terrorists appears to be inversely proportional in the two systems. Whereas the pursuit of political aims tends to heighten or perhaps establish the correspondence between publicly directed violence and terrorism in American law, in Islamic law it 
tends to have the opposite effect. In other words, to the extent that a group declares itself or is deemed by the government to be acting in pursuit of political objectives (and the assumption here is that these are grounded in some interpretation of religion), their activity is actually less likely to fall under the law of biräbah. Second, the importance attached to numbers appears to be inversely proportional in the two systems. Under Islamic law, the greater the number of individuals involved in a prima facieact of terrorism, the lesslikely to fall under the laws of biräbah. By comparison, according to FBI guidelines issued in 1983, a terrorism investigation may not even be initiated unless circumstances indicate that two or more persons are involved in an offense. ${ }^{6}$ Third, birabah, at least in its fully developed form, appears to be potentially a much broader category than terrorism proper, covering as it does a spectrum of crimes ranging from breaking and entering to "hate crimes" to rape to terrorism proper. Here, however, given the broad range of criminal statutes under which most terrorists are prosecuted in the United States, this difference may turn out to be more apparent than it is real. Indeed, few terrorists are actually tried in America for bona fide acts of terrorism perse. Instead, they are usually pursued and prosecuted on charges having to do with trafficking in or possessing illegal weapons, money-laundering, or attempts to conceal and/or falsify identity. ${ }^{7}$ Finally, whereas American law appears to target terrorism that is directed toward the realization of goals that lie beyond acts of violence themselves, Islamic law punishes terrorism, period, be it directed beyond or merely coincidental to the occurrence of a violent or heinous act.

At the outset, I would like to say a word about the nature and structure of the Islamic legal system. Islamic law represents what some scholars have referred to as an extreme case of "jurists' law." Being neither the product nor preserve of the early Islamic state, it developed in conscious opposition to the latter. Private Muslims in pious devotion to the study of scripture, during the first two centuries of Islam, succeeded in gaining the community's recognition for their interpretive efforts as constituting the most authentic representations of divine intent. By the middle of the $3^{\text {rd }}$ Islamic/ $/ 9^{\text {th }}$ Common Era century, a full blown legal theory had developed, with the Qur'ann, the Sunna (or normative practice of the Prophet), and the consensus of the jurists as the sources of Islamic law, and analogy (qiyas) as the primary means of extending these to treat unprecedented cases. During this same period, the jurists began to organize themselves into guilds or schools of law, called madbbabs, and by the end of the $4^{\text {th }} / 10^{\text {th }}$ century, the madbbab had emerged as the sole repository of legal authority. From this point on, all interpretive activity, if it was to be recognized as authoritative or "orthodox," would take place within a recognized school of law. By the end of the $5^{\text {th }} / 11^{\text {th }}$ century, the number of 
Sunni madbhabswould settle at four, at which number they would remain right down to modern times. These were the Hanafì, Mālikī, Shãfi ‘ and Hanbali schools, all equally orthodox, all equally authoritative. The main branch of Shicism, the Imāmi Twelvers (with whom I will not have occasion to deal in this paper) had one main madbbab, the Ja 'fari school. These schools continued to maintain their monopoly over legal authority and interpretation unchallenged until the introduction of Western legal and educational systems during the colonial period.

\section{Ḥirābah $=$ Terrorism}

The obvious starting point in any attempt to establish correspondence between terrorism and birabab is with the definitions of these terms. In the United States, the agency charged with investigating real and suspected instances of terrorism is the $\mathrm{FBI}$, which defines terrorism as, . . the unlawful use of force or violence against persons or property to intimidate or coerce a government, the civilian population, or any segment thereof, in furtherance of political goals. ${ }^{8}$

A prominent, if not essential, ingredient of this definition is clearly its focus on intimidation, i.e. the desire to induce and/or spread fear. ${ }^{9}$ This fear, however, is not merely coincidental to the occurrence of heinous acts but is directed toward the realization of goals that lie beyond the acts themselves. This is in fact what distinguishes an act of terrorism-e.g. the 1996 bombing of the Federal Building in Oklahoma-from a random act of violence, such as the shooting at Columbine High School in Littleton, Colorado. ${ }^{10}$ While both of these acts engendered widespread public fear, the bombing of the Federal Building appeared to be directed at a target beyond its immediate victims. The United States government, in other words, or society at large, was being called upon to implement certain changes, in the absence of which society could expect more violent action. In this context, adherence to the status quo, or life as we know it, came to represent an imminent threat to everyone's safety. It is this kind of intimidation or spreading of fear that lies at the heart of terrorism in American law.

When we turn to classical Islamic definitions of birabah, we find that here too the elements of intimidation and spreading fear are central. The Spanish Mäliki jurist Ibn 'Abd al-Barr (d.463/1070) defines the agent of biräbab as "Anyone who disturbs free passage in the streets and renders them unsafe to travel, striving to spread corruption in the land by taking money, killing people or violating what God has made it unlawful to violate is guilty of biräbah . . . be he a Muslim or a non-Muslim, free or slave, and whether he actually realizes his goal of taking money or killing or not."11 The 
Hanafí jurist, al-Kāsāni (d.587/1191) defines ḅiräbab (or qaț al-taríq) as "attacks upon pedestrians for the purpose of taking money by force and in such a way that people are rendered unable to pass freely through the streets . . . "12 Imām al-Nawawi (d.676/1277) states that, "Whoever brandishes a weapon and terrorizes the streets (akbafa al-sabil) inside or outside a city must be pursued by the authorities (al-Imãm), because if they are left unmolested their power will increase and through their killing and taking money and corruption will spread." ${ }^{13}$ Ibn Qudāmah (d.620/1223) defines biräbah as "the act of openly holding people up in the desert with weapons in order to take their money." 14 He notes, however, that many of his fellow Hanbalites held that such wanton brigandage constituted biräbab whenever it occurred, "because it is even more frightening and detrimental inside cities." 15

In their elaborations, these jurists confirm that biräbab is distinguished by its connection to the spreading of fear (ikhafah) and helplessness ('adam al-ghawth) and the fact that no effective security measures can be taken against it (ta'adhdhur al-ibtiräz). The Shâfi'i jurist, al-Nawawi, for example, notes that early authorities like Mālik (d.179/795) and Abū Ḥanifa (d. 150/ 767) ${ }^{16}$ restricted their designation of birabab to acts committed in unpopulated, isolated areas, because it was only in these areas that people were really rendered helpless. Urban victims would always be surrounded by other people who could conceivably come to their aid. ${ }^{17}$ This is the underlying logic of Ibn Qudamali's discussion, which limits birabab to acts of brigandage committed in the desert. ${ }^{18}$ In a similar vein, the majority of Shäfi'is are reported to have held that if a group storms a man's house with the intention of robbing him and then threatens to kill him if he makes any noise, their effort to silence him would disqualify their crime from being considered an act of biräbab, because their attempts to conceal their presence from the neighbors would contradict any intention to spread fear and helplessness. ${ }^{19}$ Meanwhile, the famed Hanbali Ibn Taymiyah (d. 728/1328) registered an opposing view but for reasons that confirm the centrality of spreading fear and helplessness. He says that if renters, doctors or craftsmen lure people into their places of business in order to kill them by stealth (ostensibly for the purpose of taking their money), then these offenders are guilty of biräbab because, "killing by stealth (ghilab) is like killing with no regard for who is watching (mukabaratan), and no security measures can be taken against either of these (wa kilabuma la yumkin al-ibtiräz minh).$^{20}$ Essentially the same point is made by al-Kāsāni, but this time with an interesting twist. He notes that a number of Hanafi jurists, beginning with the eponymous Abu Hanifa himself, exempted women altogether from the law of birabah, based on their belief that women, though perfectly capable of 
both killing and robbing, were incapable, by their very constitution, of bringing about widespread fear and helplessness. ${ }^{21}$

The element of helplessness provides the basis for a number of interesting modifications in Islamic criminal law. For example, under the law of intentional homicide (qisäs), the general rule, accepted by all but the Hanafis, is that the murder of a non-Muslim by a Muslim is a civil offense for which the family of the victim can only demand blood money, not execution, as would be the case if the victim was a Muslim. A number of jurists insisted, however, that in some instances such murders constitute acts of biräbab for which the Muslim perpetrators are to be executed. Now, what qualifies such a murder as an act of biräbab appears to be the lack of any personal relationship between the parties, such that the victim might either be able to reconcile with or to avoid persons with whom he has antagonistic relationships. In other words, the fact that the Jewish or Christian victim does not know his killer implies that the killer targeted not simply this Jew or this Christian but rather any Jew or any Christian. As such, no Jew and no Christian would be safe, because they could not take any security measures against such an equal opportunity killer. Thus, we find even the reputedly puritanical Ibn Taymiya, his polemical theological writings against Jews and Christians notwithstanding, insisting that the strongest opinion among those espoused by the jurists was that the Muslim murderer in such cases must be executedas a duty, incidentally, upon the authorities, not at the behest of the victim's family-"because," according to him, "this is a crime against the public at large (li annabu qatala li al-fasäd al-'ämm)."22 Similarly, a number of later Māliki jurists, e.g. al-Dardir, al-Șāwì, imply that if a Muslim forcibly enters a non-Muslim's house and the latter ends up killing him in defense of his property and/or the honor of his family, such a killing would be treated essentially as an act of "self-defense." 23

In most if not all of these depictions, the money-taking motive appears to lurk in the background as a consideration alongside the spread of fear and helplessness in judging acts as constituting instances of biräbab. From this perspective, the definitions and elaborations cited appear to be more suggestive of something along the lines of armed robbery, banditry or extortion than they are of terrorism perse. Closer examination reveals, however, that while the money-taking motive is clearly a consideration, this is simply because money-taking was the most commonly assumed reason for why individuals engage in acts of biräbab, not because money-taking was itself a sine qua non. The sine qua non of biräbab was, again, the spreading of fear and helplessness. This is most clearly manifested among Mâliki jurists (especially later Mãliki jurists) in the distinction they draw between biräbab and $g h a s b$ (unlawful appropriation). 
In his al-Sharb al-sagbir, Ahmad al-Dardir (d.1201/1786) cites the definition of ghasb given by Ibn al-Häjib (d.646/1248) as the going definition in the Māliki madbbab. According to this definition, ghasbconsists of: forcibly and wrongfully taking another's money without engaging in biräbab (akbu mäl qabran ta 'adìyan bi lä biräbab). ${ }^{24}$ Al-Dardīr points out that this definition is actually defective inasmuch as it relies upon prior knowledge of the definition of birabab. He notes, however, that this deficiency can be easily overcome by substituting "without inspiring fear of being killed (bi la kbawfi qatlin)" for "without engaging in biräbah." In other words, biräbab is distinguished from gbasb not by the element of taking money but by the element of inspiring fear for one's life. This fear, however, goes beyond the immediate victim (who is obviously afraid and for that reason gives up his money) and has the effect of discouraging others from undertaking their normal course of activity, again, out of fear for their lives. This is clearly brought out in another manual by al-Dardir, al-Sharb alkabir, wherein he states that if the victim of such robberies has immediate access to people who could come to his rescue, then the act of taking his money would not constitute an act of hiräbab but an act of ghasb.25 In other words, the presence of people to come to his aid both precludes the spreading of fear and preempts the occurrence of helplessness, both of these being essential elements that define biräbab and set it apart from ghasb, which, incidentally, carries only discretionary sanctions, as opposed to the harsh mandatory punishments for biräbab.

On this understanding, later Māliki jurists isolate the spreading of fear and helplessness as the ration essendiand extend the scope of birabab to cover all sorts of crimes where the money-taking motive is completely absent. Al-Dardir, for example, defines biräbab explicitly as ". . . blocking the streets (qät al-tariq), i.e. terrorizing them (yukbifuba) by preventing their free passage, i.e. by preventing people from freely traveling them, even if there is no attempt to take their money." 26 His $13^{\text {th }} / 19^{\text {th }}$ century commentator, Ahmad al-Șāwi (d.1241/1825), in explaining the last sentence adds "Even if his aim is merely to prevent people from enjoying the benefit of freely traveling the streets (law qasada mujarrad man' al-initifa' bi almurür fibä). "27 Another commentator, Shams al-Din al-Dasūqi (d.1230/ 1815), is even more explicit in his clarification. He writes,

One who engages in birabab is one who terrorizes the streets (akhafa al-farig) in order to prevent people from freely traveling them. That is to say, it is anyone who terrorizes the people in the streets in such a way that prevents them from freely traveling them and from enjoying the benefit thereof, even if he does not aim to take their money but rather 
only to prevent them from enjoying the benefit of freely traveling the streets. . . ${ }^{28}$

As with other authorities mentioned, al-Dasūqi goes on to apply this notion of spreading fear and helplessness to any situation in which individuals are rendered helpless. This brings him to endorse the controversial principle to the effect that all acts of murder committed by stealth, e.g. poisoning, drugging (and, by extension, more modern activities such as carbombings), fall under the law of biräbab. ${ }^{29}$ To be sure, these jurists all recognized how problematic and dangerous such a broad construction of birabab could be. Thus, we find them laying down all kinds of riders and qualifiers that would set biräbah off from more routine acts of theft, robbery, pilferage, murder and the like. In the end, however, biräbab assumes its place as an effective super-category hovering above the entire criminal law as a possible remedy to be pressed into service for the more sensational, heinous or terrifying manifestations of these and other crimes. In this capacity, biräbab appears, again, to parallel the function of terrorism as an American legal category. Its function is not so much to define specific crimes but to provide a mechanism for heightening the scrutiny and/or level of pursuit and prosecution in certain cases of actual or potential public violence. ${ }^{30}$

In sum, we may conclude that it is terror, or the spreading of fear and helplessness, that lies at the heart of biräbab. From this perspective, birabab speaks to the same basic issue as does terrorism in American law. As mentioned earlier, however, biräbab actually goes beyond the FBI definition of terrorism, inasmuch as biräbab covers both directed and coincidental spreading of fear. Thus, for example, both the bombing of the Federal Building in Oklahoma and the shooting at Columbine High School in Colorado would fall under the law of birabab. So too would the 1999 shooting at the Jewish community center in California ${ }^{31}$ and the 1998 sniper assassination of the abortion doctor inside his New York home. ${ }^{32}$

\section{Punishments}

Hiräbab, it turns out, is the most severely punished crime in Islam, carrying mandatory criminal sanctions (budud/s. badd). A typical explanation for the severity of these sanctions is given by the $7^{\text {th }} / 13^{\text {th }}$ century Spanish Māliki jurist, Muhạmmad b. Aḥmad al-Qurțubi, who writes,

Hiräbab is extremely detrimental because it prevents people from being able to earn a living. For, indeed, commerce is the greatest and most common means of earning a living, and people must be able to move about in order to engage in commerce. . But when the streets are terrorized (ukbifa), people stop traveling and are forced to stay at home. 
The doors to commerce are closed and people are unable to earn a living. Thus, God instituted the severest punishments for birabab as a means of humiliating and discouraging the perpetrators thereof and in order to keep the doors of business open. ${ }^{33}$

The severest punishments to which al-Qurțubi refers are explicitly outlined in Quraan, 5:33-34, virtually the beginning and end of all juristic discussions on biräbah.

Verily the recompense for those who wage war against God and His Messenger and strive to spread corruption in the land is that they be executed or crucified or that their hands and feet be amputated from opposite sides or that they be banished from the earth. That is for them a humiliation in this life, and in the Next Life they shall receive a grievous chastisement. Except for those who repent before you are able to subdue them. And know that God is Forgiving, and Merciful.

These punishments are quite straightforward, as a result of which the jurists display a great deal of unanimity in their interpretations of these verses. Still, there were disagreements. The first of these was over the meaning of "or" ( "aw"in Arabic) that separates these punishments from each other. The majority, the Hanafis, Shäf is and Hanbalis, held that "or" implied a kind of ascending order (tartib) commensurate with the particulars attending the act of birabah. If the terrorists killed people without taking any money, they were only subject to execution; if they killed people and took money, they were subject to execution and crucifixion (in that order, according to some; in the reverse, according to others); if they did not kill but only took money, they were subject to having their right hand and left foot amputated; and if they neither killed nor took money, they were only subject to exile, some, like the early Hanafis, interpreting this to refer to imprisonment. ${ }^{34}$

The big dissenters on this question were the Mãlikis, who, in cases that did not involve killing, left the choice of punishment entirely to the discretion of the authorities. In the Mãliki view, one guilty of biräbah could be executed or crucified even if they neither killed nor took money. Their reasoning was that the spreading of fear, helplessness and a host of other evils could result from an act of biräbab that involved no killing or robbery. Indeed, Mālik himself is on record as having once remarked that "Many a one is there who commits biräbah who does not kill but who spreads more fear (buwa akbwaf) and is more detrimental to society in the fear that he spreads (a'zamu fasadan fi khawfib) than one who actually kills people." 35

A second disagreement arose over the amount of property a terrorist would have to take in order to be subject to amputation. According to the 
law of theft, the property stolen by a thief must exceed a certain value ( $n i s a b$, i.e. $1 / 4$ dinar, or about $\$ 16.94$, according to my calculations) in order for the thief to be subject to punishment for theft. The question then arose as to whether this logic should extend to the law of biräbah. The Shäficis, ${ }^{36}$ Hanabalis ${ }^{37}$ and a majority of Hanafis (with some qualifications) ${ }^{38}$ held that it did. The Mālikis held that it did not, and for them, one guilty of biräbab was subject to amputation regardless of the value of the property taken.

A third disagreement involved the question of whether accomplices (rid') who were not directly involved in any killing (or robbing) were subject to execution (or other punishment) along with the actual killers. The Shäficis held that only those directly responsible were subject to execution. ${ }^{39}$ The Hanafis, Mâlikis and Hanbalis, meanwhile, held accomplices equally responsible. $^{40}$

On the question of repentance and their interpretation of the verse "Except those who repent before you are able to subdue them," all of the schools agree that if one repented before being apprehended, e.g. by turning oneself in and displaying plain indications of a change of heart, the mandatory criminal sanctions (execution, crucifixion, amputation and exile) were to be dropped, as "rights of God (bagq Alläb); And know that God is Forgiving, Merciful." Civil liability (baqg al-ädami), however, the right of a victim's family to demand execution or reimbursement for stolen or damaged property, could not be set aside. ${ }^{41}$

These were some of the most important differences regarding the punishments for biräbah discussed by classical jurists and their heirs.

\section{Restrictions: Hịrābah vs. Political Speech}

The severity of the punishments for birabab caused jurists to develop another set of qualifications that would effectively separate biräbab from acts that may be interpreted as constituting a form of political speech, so as not to sacrifice the latter to a sloppy and overinclusive construction of the former. This had less to do with any strict application of agreed upon rules of scriptural interpretation than it did with practical considerations in response to concrete historical circumstances. The early history of Islam was fraught with a number of religio-political schisms that often led to open rebellion. The most important of these were the rebellions against the fourth caliph, 'Alī b. Abì Tâlib, first by the Companions, Talhaha, Zubayr and ' $\bar{A}$ 'ishah, then by the governor of Syria, Mu'āwiyah b. Abì Sufyăn, and then by the Khārijites, who finally succeeded in assassinating 'Ali. 'Alī's clemency in dealing with these insurgents, in his capacity as head of the Muslim state, set a precedent that would later exert a major influence on juristic discus- 
sion. The Umayyads, meanwhile, 'Alì's former foes who succeeded him on his death, and then the 'Abbãsids after them, were not so kindly disposed towards rebels. Their tendency was rather to apply the very severest punishments outlined in the discourse on biräbab to rebels and political dissidents. It was against this tendency that jurists developed a separate law, the law of rebellion (abkäm al-bughät), based on Quraan 49:9-10 ${ }^{42}$ and the precedent set by Ali $b$. Tälib. Under this law, insurrections were simply to be put down, captured rebels could be neither executed nor tortured, and after the rebellion had been crushed and the rebels repented, they were simply to be set free with no punishment. They were not liable for any killing or property damage committed during the course of the rebellion. They could only be punished, according to some jurists, for "crimes" unrelated to the success of the rebellion; rape, for instance. ${ }^{43}$

There were essentially two major considerations on the basis of which an act of biräbab was to be distinguished from an act of bagby, or rebellion. It is in light of the considerations I stated earlier that the significance attached to numbers and the political motivations of would-be terrorists appears to be inversely proportional in Islamic and American laws of terrorism.

The first of these considerations was that the rebels be motivated by what jurists referred to as a taivil, or "a plausible interpretation" that might justify, at least in their minds, rebellion as a means of redress or of carrying out the Quranic imperative to command what is good and forbid what is evil. It does not matter if the interpretation is "wrong" or even heterodox; what matters is that it be plausible; that the language of the Qur'ān and/or Sunna or the circumstantial and contextual indicators surrounding this language could accommodate such a reading. In fact, the focus of the rebels' interpretation might even be purely "political" as opposed to religious. It is commonly agreed, for example, that Talhah Zubayr and ' $\bar{A}$ 'ishah (the wife of the Prophet) all relied on a plausible interpretation in rising against 'Ali, though the issue under dispute was purely political, namely, 'Ali's refusal to pursue the murderers of his predecessor, 'Uthmān. ${ }^{44}$ In sum, it is essentially the appearance or the rebels' insistence that their actions are based on their understanding of their duty as Muslims that confers upon these actions the status of "political speech." This sets them apart from criminal acts of

\section{biräbah.}

The second stipulation was that the rebels be backed by a sufficient level of force (sbawkab), measured mainly in numbers and military preparedness. ${ }^{45}$ The jurists differed on this number. The $7^{\text {th }} / 13^{\text {th }}$ century al-Qarāfi notes that a number of jurists placed it at ten; but he of all people would admit that this was a question of fact, not law, and that this number could increase or decrease, depending on the jurists' and/or the authorities' assess- 
ment of the situation. ${ }^{46}$ This stipulation has the effect of reserving the more lenient law of rebellion for the most serious and widespread cases of public disaffection. That is to say, the greivances that allegedly prompt a group to rebel must be serious and widespread enough to enlist the support of significant numbers of people. Otherwise, small groups of extremists, sophomoric idealists, prurient bandits or terrorists will be denied the refuge afforded by the law of rebellion and be treated under the more severe and salutary law of biräbab.

\section{Hịābah in Twentieth Century Muslim Discourse}

Legal discussions of birabab in the $14^{\text {th }} / 20^{\text {th }}$ century follow, for the most part, the contours laid down in premodern times. The definitions remain essentially the same and the creative process by which premodern jurists extracted the law of biräbab from Qur'ann 5:33-34 is only perfunctorily questioned and then confirmed. In terms of the substance of the law, nothing of note is really added or taken away. There is, however, at least one new thrust or orientation that seems to have begun, as far as I can tell, with the reformers Muhammad 'Abduh, once Grand Mufti of Egypt (d. 1905), and especially his student Muhammad Rashid Riḍã (d. 1935). This was the tendency to view birabab not simply as a threat to public security in general but more specifically as a threat to the sanctity and application of Islamic law as a legal system. Riḍa, for example, defines biräbab as "the commission of acts in the lands of Islam that threaten the security of life, property and honor, while seeking immunity in the power of one's group and refusing to submit willingly to the religious law." ${ }^{47}$ In other words, by birābah, Riḍa is referring to the actions of those who arm and organize themselves explicitly for the purpose of preventing the application of religious law either to themselves or others. ${ }^{48}$ Writing at a time when Islamic law was still in the process of losing ground to Western European laws, preference for which was now expressed and acted upon by indigenous Muslim rulers, it is easy to imagine the genesis and target of these views. ${ }^{49}$ Under the Tanzimat reforms of 1839-76, for example, the Ottomans adopted a Commercial Code that was essentially a direct translation of the French Commercial Code (including provisions for the payment of 'interest' (riba) a Penal Code that was essentially a translation of the French Penal Code (which abolished all of the badd punishments [ birabab being one of them] ${ }^{50}$ except for that governing apostasy), a Code of Commercial Procedure and a Code of Maritime Commerce, both of which were based on French law. From 1875 on, Egypt went even further than the Ottomans in their adoption of Penal, Commercial, Maritime and even Civil Codes, modeled almost exclusively on French law. ${ }^{51}$ 
Given this context, one can see how Rid̦ā's definition might have been read as an indictment of Muslim (and more specifically, Egyptian) rulers whose departures from traditional Islamic law he wanted to highlight as a proper concern of the law itself. Subsequent history would show Ridâ to have laid an important brick in the ideological foundation of resurgent Islam.

But Ridân's view did not have the immediate effect of displacing the traditional view. Rather, it would contribute to a phenomenon, quite common in Islamic law, of old and new views running parallel to each other as proponents of each jockeyed to establish theirs as the dominant view. ${ }^{52}$ With the traditional perspective clearly still incumbent, both of these views would be reflected, in varying degrees, in the writings of subsequent jurists all the way down to the present day. Shaykh Muhammad Sayyid al-Tanțāwī, for example, former Grand Mufti of Egypt, now Rector of al-Azhar College of Islamic Law, alongside the traditional definition, speaks of biräbah as being the activity of those "who oppose the religious community's established order" (yubäribuin al-nizäm al-qäim li al-ummab). ${ }^{53}$ Shaykh Wahbah Zuhayli of Syria writes that the only difference between birabab and baghy (rebellion) is that the latter opposes the legitimate ruler on the basis of a "plausible religious interpretation" (ta'wil), while the former does so without any such pretense. ${ }^{54}$ The most far reaching manifestation of the new orientation of 'Abduh and Rid̄a appeared in the work of a non-jurist, 55 the Egyptian one-time chief ideologue of the Muslim Brotherhood, Sayyid Quţb, who was executed in Egypt in 1966.

In a move typical of non-jurist activists, Qutb begins not with figh, or the legal discourse of the jurists, but with the Quraan itself. This enables him to avoid having to fit (or perhaps force) the Quraan into preexisting constructs of jurists; rather, he can interpret the Qur'àn according to his own lights and then fit whatever aspects of jurists' discourse he sees fit into this. He begins with Qur'ān 5:33-34 and defines biräbab as "the act of rising, through organized rebellion, against the legitimate Muslim authority (al-Imäm al-Muslim) who rules in accordance with the Law of Islam, in defiance of the latter's authority, intimidating the Muslim population, and assaulting their persons, property and honor." ${ }^{56}$ For Quţb, the essential charactaristic of biräbab is the fact of its occurring in opposition to legitimate Muslim authority. But the sine qua non of legitimate Muslim authority is not simply the process by which an individual comes to power but the faithful application and upholding of the shari'a. Thus, Quțb rails against those traditional jurists who sanctioned the application of the punishment for biräbabagainst those who rebelled against ostensibly Muslim rulers who did not derive their authority from religious law. According to Qutb, this completely undermined the intent of the law of biräbab; for, in many instances, such revolts were being 
waged not against God and His Messenger but against Muslim rulers who flaunted the law of God. ${ }^{57}$ From here, it is a very short and easy step to the conclusion that "legitimate Muslim authority" is not synonymous with the state but may apply to any collectivity actively involved in establishing a social and political order based on the law of Islam. ${ }^{58}$ In this way, Quţb is able to challenge the legitimacy of the secular Egyptian state and to declare it to be the object of Qur'ann 5:33-34. According to him, spreading corruption and opposing God and His messenger are the target of these verses, and there can be no greater corruption or opposition to God and His messenger than the dismantling of Islamic law. ${ }^{59}$ On this understanding, combating corruption becomes the central focus of biräbab for Quțb. Meanwhile, the near obsession with general issues of public security that we saw in the discussions of the classical jurists palpably recedes into the background.

To be sure, Qutb's views were not without precedent in the early history of Islamic jurisprudence (though he himself seems not to have relied on this). Indeed, a number of early jurists had associated birabab with the activities of groups who had formally apostatized and resorted to violence in an attempt to overthrow the Islamic social and political order. ${ }^{60}$ The classical jurists, however, as we have seen, would reject this restriction and construct a law of birabah that would include non-apostate terrorists, on the one hand, and exclude non-apostate rebels, on the other, providing in the case of the latter an alternative to complete annihilation. Ironically, it would be precisely those modern secularizing forces which equated their success with their ability to marginalize traditional legal authorities (whom they saw as standing in the way of progress) who would create the space in which views like Qutb's would ultimately gain currency, particularly among young, ideologically hungry and economically disenfranchised segments of the population.

\section{Conclusion}

Throughout Islamic history, Muslim jurists showed themselves to be keenly interested in protecting the community from those within its midst who seek to bring it harm through violence and terror. Early on they would turn to Quraan 5:33-34 to provide them with the means to develop legal constructs that served this interest. The law of biräbab was the result of this effort. Far from a stagnant construct, however, biräbab turned out to be an extremely malleable category, capable of assuming many different forms under many different circumstances. Indeed, the many features and different applications of the law of birabab show themselves to have been just as indebted to historical experience and the creative acumen of jurists as they were to dictates of scripture. At bottom, however, the primary concern 
remained essentially the same as that governing discussions of terrorism in American law: protecting the community against publicly directed violence. Even the modern revisionist approaches would not completely abandon this interest. Viewed from this perspective, we can see a clear cognate relationship between terrorism in American law and biräbab in Islam. Such recognition should encourage a more informed comparison between Islamic and American legal approaches. At the very least, such an exploration could deepen our confidence in the ability of the two systems to speak to and understand each other. At most, it might point the way to possible avenues of cooperation in a mutually shared interest in a safer, better world.

\section{Endnotes}

Versions of this paper were delivered in November, 1999 at the University of Michigan Law School and in February, 2000 at Georgetown University Law School.

1. I limit my discussion in this paper to domestic terrorism because a discussion of international terrorism would take us into the complicated issue of extraterritoriality and the question of the applicability of Islamic law outside the lands of Islam, an issue on which the jurists differed widely. For example, the Hanafi jurist, al-Kāsãni, asserts that there is no punishment for terrorism in non-Muslim lands, "because the one responsible for applying such punishments is the Imãm (Muslim authority), and he has no jurisdiction in non-Muslim territories (dar al-barb)." (See 'Alā' al-Din Abū Bakr b. Mas'ūd al-Kãsãni,

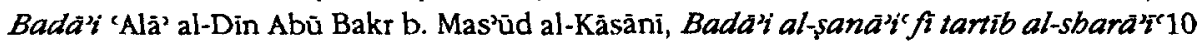
vols. (Beirut: Dār al Kutub al-'`lmìyah, 1418/1997), 9:363. Meanwhile, the founder of the second largest school of Islamic law, Mãlik b. Anas, insists that Muslims who commit acts of terrorism in "dar al-barb" are to be executed. He does not tell us, however, wbo is to undertake such execution. ISee, al-Mudawannh al-kubrä, 4 vols. (Beirut: Dār al-Fikr, 1406/1986), 4:431.J Clearly, a definitive statement on this matter would require a diachronic survey of the schools of law in order to assess the extent to which these views were sustained and/or modified over time.

2. Walter Laqueur, The Terrorism Reader(Philadelphia: Temple University Press, 1978), 1-2, notes that discussions on terrorist theory and practice go back at least as far as the 1880 s and 1890 s. These, however, appear to have been more along the lines of academic discussions, exerting little effect on public perception or legal discourse.

3. See B.L. Smith, Terrorism in America (New York: State University of New York Press, 1994), 8.

4. Ibid.

5. Even as informed an authority as Khäled Abou El-Fadl in his excellent article on abkäm al-bugbatmisses the parallels between birabab, qat 'al-tariq and terrorism. He writes "The former /hirabab] deal[s] with common criminals motivated by private gain." See Khāled Abou El-Fadl, "A bkaim al-Bughat: Irregular Warfare and the Law of Rebellion in Islam, Cross, Crescent and Sword: The Justification and Limitation of War in Western and Islamic Tradition, eds. J.T. Johnson and J. Kelsay (New York: Greenwood Press, 1990), 151. Meanwhile, the study by D.A. Schwartz, "International Terrorism and Islamic Law," Columbia Joumal of Transnational Law, 29 no. 3 (1991): 629-52 is emphatic and not 
wholly uninformative. But the author's inability to consult the primary sources of Islamic law and his lack of familiarity with the tradition of legal discourse in Islam force him to rely on Western sources (in translation) and to employ a cut-and-paste method, the results of which few, if any, Muslim jurist would recognize as an authoritative position.

6. Smith, Terrorism, 12.

7. In fact, almost all of the offenses for which terrorists have been traditionally pursued and prosecuted can be subsumed under existing criminal laws and statutes. Among the most common of these are: 1) racketeering; 2) machine guns, destructive devices and other firearms; 3) conspiracy; 4) racketeering-influenced and corrupt organizations (RICO); 5) firearms; 6) explosive materials; 7) stolen property; 8) robbery and burglary; 9) international emergency economic powers; 10) treason, sedition and subversive activities; 11) mail fraud; 12) homicide; 12) fraud/false statements. See B.L. Smith, Terrorism, 162-63.

8. Ibid., 6 .

9. See Benjamin Netanyahu, Terrorism: How the West Can Win (New York: Farrar, Straus, Giroux, 1986), 9.

10. On April 20,1999, two students, Dylan Klebold (18 years old) and Eric Harris (17 years old) opened fire on their classmates at their high school, killing thirteen people and wounding several others. This constituted the worst act of violence to occur at an American school in U.S. history. See Newsweek (3 May, 1999): 22-31.

11. Al-Kâfift figh abl al-medinab al-mäliki, (Beirut: Dār al-Kutub al-'llmiyah, 1418/ $1997,582-83$.

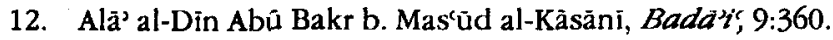

13. Al-Nawawi, Kitab al-Majmǘ; 23 vols. (Cairo: Dãr Ihyā' al-Turāth al-'Arabī, 1415/ 1995), 22:227.

14. Al-Mughni, 14 vols. (Beirut: Dār al-Kutub al-'Tlmìyah, N.d.), 10:315.

15. Ibid., 10:303.

16. Al-Majmü, 22:232.

17. Ibid.; al-Mughni, 10:303.

18. Al-Mughni, 10:303.

19. Al-Nawawi, al-Majmǘ, 22:233. This view did not last. In fact, some eventually held that such violence inside cities where people are supposed to be safe was even more criminal in nature, since they bespoke a certain boldness and disregard for civil society. See; e.g. Ibn Taymiyah, Majmī' fatäwä ibn taymijyah, 28:315-16. Ibn Taymiyah adds, incidentally, that when people are robbed in their homes, they can be dispossessed of all their wealth, whereas people traveling in the desert usually only have a portion of their wealth with them.

20. Ibid., 28:316.

21. Al-Kāsāni, Badàì, 9:361. Later Hanafis, e.g. al-Tahāwī, opposed this view.

22. Mujmü fatawa, 28:311. A possible parallel to "hate crimes," the issue was disputed in the Shäfi'i school. Those who held that execution was the right "right of God" (bagq Allab), held that the murderer was to be executed; those who held it to be the right of the victim's family (bagg al-adami), held that he was not. See al-Nawawi, al-Majmis; 22:240-2. See also on the Măliki position, al-Qãdi 'Abd al-Wahhäb, al-Má̌inah, 'ala madbbab 'alim al-medibah, 3 vols. (Mecca and Riyad: Nizar M. al-Baz, 1415/1995), 2:1366; Ibn 'Abd al-Barr, al-Käf, 583.

23. Al-Sharb al-saghir, 2:404; Bulgbat, 2:404. Islamic law does not explicitly recognize a formal category called "self-defense." But, as we see in the present case, this does not mean that the concept itself is not operative in the law. The Shäfi'is, for example, 
speak to the issue in some detail in a chapter on "aggression" (sijail). See, e.g. Shams alDin Muḥammad b. Ahmad al-Shirbini, al-Iqná' fi ball alfáz abi shujā 2 vols. (in one) (Cairo: Muștafã al-Halabi, 1359/1940), 2:199-200.

24. Al-Sbarb al-saghir, 2:404; Bulghat, 2:209.

25. Al-Sharth al-kabir(On the margin of al-Dasūqi's Häsbiyat), 4:348.

26. Ibid., (on the margin of Bulghat al-salik), 2:403.

27. Anmad al-\$âwi, Bulghat al-salik li aqrab al-masalik ild madbhab al-imam mälik, (Cairo: al-Maktabah al-Tijāriyah al-Kubrã, n.d.), 2:403. Both authors, incidentally, confirm the stipulation of helplessness, stating that this definition applies only "assuming the lack of access to those who could extricate one (yata 'adbalbar machu al-gbawth)." See Bulghat, 2:404.

28. Hasbiyat al-dasügi 'ala al-sharb al-kabir, 4 vols. (Cairo: Dār al-Fikr, n.d.), 4:348. Al-Dasũqi would add, incidentally, that accosting people sexually was worse than taking their money. Thus, "whoever goes out to terrorize the streets with the aim of forcing themselves upon people sexually (li al-ghalabab cala al-furuj) commits an act of biräbab more heinous than those who go out to terrorize the streets in order to take people's money." Ibid.

29. Hasbiyat al-dasüqi, 4:349. All three authors make passing reference to "state terrorism," al-Sāwi (and in his words, al-Dasuqi) even referring explicitly to "the tyrannical governors of Egypt, among others, who despoil the Muslims of their money, deny them their wages and attack their villages, while there is no one who could come to their assistance." See Bulghat, 2:404; Häshiyat al-dasüqi, 4:348.

30. See above, note 7 .

31. On 10 August, 1999, Buford D. Furrow, an avowed white supremacist, opened fire at the North Valley Jewish Community Center in Granada Hills, CA, wounding three children, one teenager and an elderly receptionist. See, Newsweek (23 August, 1999): 2325.

32. On 26 October, 1998, an anti-abortion sniper shot through the window of the home of Dr. Bernett Slepion and killed him. See The New York Times, (27 October, 1998): B-5.

33. A-Qurțubi, al-Jāmir li ableam al-qurānn 11 vols., ed. K. Mays (Beirut: Dār al-Fikr, 1419/1999), 3:88.

34. Badä'í, 9:370-71.

35. Al-Mudawwanab, 4:428.

36. Al-Nawawi, al-Majmü'; 22:233

37. Ibn Qudàmah, al-Mughnī, 10:212-13.

38. A-Kāsāni, Bada'í, 9:363.

39. A- Nawawì, al-Majmü', 22:234; Abũ al-Hasan 'Alī b. Muhammad b. Habỉb alMāwardi, al-Hawì al-kabir fífígh al-imäm al-sbaji, 19 vols. (Beirut: Där al-Kutub al'Ilmiyah, 1414/1994), 13:363.

40. A-Mãwardī, al-Häwī, 13:363; Ibn Qudāmah, 10:308; al-Mudawwanah, 4:430.

41. Al-Nawawī, al-Majmü', 22:242-43; al-Kāsāni, Badā't', 9:373-74; Ibn Qudāmah, alMugbni, 10:314-15; al-Dardir, al-Sharb al-sagbir, 2:404-05.

42. "If two parties of the faithful come to arms, reconcile between them. If, one of them then transgresses against the other, fight the one that transgresses until it returns to the command of God. If it returns, reconcile between them justly and be fair. Verily God loves those who are fair. Verily, the faithful are but a single brotherhood. So reconcile between your brothers, and be God-conscious, perhaps you might receive mercy."

43. See Khāled Abou El-Fadl, "Abkäm al-bugbät,"153, 160.

44. See Khāled Abou El-Fadl, "Abkàm al-bughät,"157-58.

45. See Khāled Abou El-Fadl, "Abkam al-bugbat," 160. 
46. Al-Qarāfĩ, al-Dhakbirab, 14 vols. (Beirut: Dār al-Gharb al-Islāmī, 1994), 12:6. Among pre-modern jurists, al-Qarafi was perhaps the most articulate and emphatic in insisting that jurists recognize the distinction between law and fact and that their own jurisdiction is, properly speaking, limited to questions of law (i.e. scriptural interpretation). It is for this reason that he would insist that the number of participants in a prima facie act of rebellion could go above or below ten, depending on the assessment of qualified determiners of fact. For more on this point, see my Islamic Law and the State: The Constitutional Jursiprudence of Shibab al-Din al-Qarafi(Leiden: E.J. Brill, 1996), esp. 113-41.

47. Tafsir al-manär, 12 vols. (Cairo: Dār al-Manār, 1376/1946), 6:366.

48. Al-Manar, 6:358.

49. On the views of Ridā and 'Abduh, see al-Mandr, 6:352-68.

50. Abolished were criminal sanctions for fornication and adultery, theft, wine drinking and defamation (qadbap).

51. On these and other developments, see NJ Coulson, A History of Islamic Law (Edinburgh: Edinburgh University Press, 1964), 151-52ff.

52. Islamic law never recognized a legislative branch of government. Rather, God was recognized as the only legislator, the shari;, the function of the jurists being to interpret the law, the function of the state being to implement it. Since there was no legislative branch, there was no mechanism for striking laws from the books, even after the collective efforts of the jurists had settled on new interpretations. This led to a peculiar feature of Islamic law not unanalogous to what we find in American law, namely that laws that had been effectively rescinded remained 'on the books' and retained their potential status as "good law" if they should ever be championed by the right authorities under the right circumstances. Failure to appreciate this fact has led to a number of lamentable instances of modern scholars (particularly those outside the field of Islamic legal studies) referring to authoritative manuals of Islamic law and citing views that may have constituted a school's going opinion at one time but had since been overridden by other views. This is particularly problematic given the common assumption that the older view must be the more "authentic," a bias that ignores the fact that Hanafi laws or Shäfiti law has always been whatever the generality of contemporary Hanafi and Shäfici jurists say it is.

53. Al-Tafsir al-wasît li al-qurān al-karim, 30 vols. (Cairo: Dàr al-Macărif, 1417/ 1996), 6:128.

54. Al-Figh al-islämi wa adillatub, 9 vols. (Beirut: Dãr al-Fikr, 1417/1996), 6:128.

55. By non-jurist, I refer to the fact that he did not receive a traditional Islamic legal education. On another level, however, one might consider him a jurist inasmuch as he engages in the activity of legal interpretation, the results of which are recognized as authentic by large numbers of Muslims, including, perhaps, a number of jurists themselves. In this capacity, Quţb, perhaps better than any other modern Muslim thinker, symbolizes one of the distinguishing features of modern Islam, namely the renewal of the competition, dormant now for more than a millennium, over whose interpretive efforts the community will recognize as constituting the most authentic representation of the divine will.

56. Sayyid Quţb, Fĩ zilal al-qurän, 6 vols. (Beirut: Dār al-Shurũq, 1393/1973), 2:878.

57. Zilal, 2:879.

58. While Quţb makes no mention of it, later Măliki writers develop a similar doctrine to the effect that if legitimate authority is non-existent or known to be corrupt, an "upright party of Muslims (Jamäat al-Muslimin al-Udül)" can be substituted as legitimate authority. This does not go as far as Quţb goes, inasmuch as it clearly recognizes the possibility of corrupt authority being legitimate. Still, it is a step in the direction of recognizing substitutes for state authority. Cf. my "Jama'at'al-Muslimin al-Udül: The 
Limits of Figh and Muslim Scriptural Hermeneutics in North America, "unpublished paper delivered at the Association of Muslim Social Scientists conference in Chicago, IL, October, 1998.

59. Zilal, 2:879.

60. The Hanafi jurist, al-jașșāș (d.370/981) goes to grcat lengths to refute the claims of "those contemporaries whose views we do not vest with authority, "to the effect that Qur'àn 5:33-34 applied strictly to apostates. See his Abkäm al-qurän, 3 vols., ed. 'Abd alSalām Muhammad 'Alī Shãhīn (Beirut: Dār al-Kutub al-'Ilmiyah, 1415/1994), 1:508-10, esp. 1:509 for the quote cited herein. 